This is a post-print version of: Wyatt, M. (2013). Motivating teachers in the developing world: insights from research with English language teachers in Oman. International Review of Education 59 (2), 217-242.

http:/ / link.springer.com/article/10.1007/s11159-013-9358-0

\title{
Motivating teachers in the developing world: insights from research with English language teachers in Oman
}

\author{
Mark Wyatt \\ University of Portsmouth, UK
}

\begin{abstract}
According to some commentators, targets set by the international community for bringing education to all children in developing countries are threatened by a teacher motivation crisis. For this crisis to be addressed, challenges to the motivation of teachers in such contexts need to be understood from perspectives both theoretical and comparative. Thus, motivation theory is required as well as analysis of the changes that have taken place in countries whose education systems have developed rapidly in recent decades. Stories of motivated teacher behaviour in such national contexts, which include the Sultanate of Oman, might be of relevance to educational reformers. Drawing upon self-determination theory, this article discusses the nature of the reported teacher motivation crisis in the developing world, highlights recent historical developments in Oman, considers the extent to which negative environmental influences on teacher motivation in Oman have been addressed and then looks for evidence of intrinsic motivation in case studies of Omani English teachers. Returning to the developing world, conclusions focus on how teachers' psychological needs for relatedness, competence and autonomy can be met through educational policies that reduce negative influences on teacher motivation and provide both inspiring professional development opportunities and work environments characterized by respect.
\end{abstract}

Keywords: teacher motivation, developing world, Oman, English language teaching, selfdetermination theory

\section{Introduction}

Research into the motivation of teachers in countries that have been fast developing ('high income' in some lists, e.g., as classified by the World Bank [2011], but 'emerging' in others) is still limited. Understanding the motivation of teachers in such contexts, though, as the education systems they work in are modernized and sometimes transformed, may be of interest to education planners in developing countries. There may be more to learn from such comparisons than from studying teacher motivation in developed countries with their very different issues. Drawing on the broad perspective of selfdetermination theory (Ryan \& Deci, 2000), this article focuses on the motivation of teachers in a fast emerging Middle Eastern country characterized by dynamic change. The country in question, Oman, was recently ranked first (of 135 countries), as the world's most improved nation over the last 40 years, according to criteria based on health, education and income (United Nations Development Fund, 2010). Before teacher motivation 
in the Omani context is examined in detail, however, the plight of teachers in developing countries is considered.

\section{Challenges to teacher motivation in developing countries}

Like all human beings, teachers "can be proactive and engaged, or alternatively, passive and alienated, [with] the social conditions in which they develop" crucial in determining how they function. Favourable social conditions can facilitate "self-motivation and healthy psychological development" (Ryan and Deci, 2000, p. 68). Unfortunately, though, in much of the developing world, these favourable social conditions are absent (Guajardo, 2011). Challenges teachers face include poverty, assignment to remote locations, poor working conditions, a lack of pre-service and in-service training, and limited professional and administrative support. Each of these challenges is discussed below and then subsequently related to Ryan and Deci's (2000) theoretical model.

Firstly, poverty resulting from low pay is a major problem in Africa and Asia, as Guajardo's (2011) research for Save the Children highlights. It can be so acute that teachers can hardly afford to eat. According to a report produced for the Department for International Development (DFID) based on data from twelve countries: "Over one-third of [the teachers surveyed] in Ghana, Sierra Leone and Zambia agreed with the statement that 'teachers in this school come to work hungry"' (Bennell \& Akyeampong, 2007, p. ix). The same authors also report of teachers from Malawi "being absent from school in order to search for food" (p. 55).

A second but related problem is that teachers are often assigned to schools in remote rural areas. Unfortunately, this can hurt them in various ways. For example, travel to the school can be more uncomfortable (e.g. if this is along pot-holed roads in Zambia) or logistically harder to organize, e.g. when the only option is air, as in Papua New Guinea (Voluntary Services Overseas VSO, 2002, p. 19). Secondly, infrastructure in remote locations is often poor, e.g. in Papua New Guinea, where hospitals, clinics and libraries were far distant and "the only facility within reach by foot was often a small shop selling kerosene, batteries and canned meat" (VSO, 2002, p. 20). A third issue is that postings to remote locations can cause loneliness in teachers when their families cannot accompany them and they are compelled to live apart, e.g. in Peru (Alcázar et al., 2006). A final dimension to the problem is lack of security in remote districts. During the recent Maoist insurgency in Nepal, teachers in fairly inaccessible, mountainous areas were frequently targeted by rebels (Bennell \& Akyeampong, 2007, p. 48).

Working conditions can also challenge teachers' motivation (Buckler, 2011). Where schools lack toilets for teachers, electricity and non-mud floors, teacher absences in India are higher (Kremer et al., 2005, p. 662). Basic classroom facilities and a lack of learning resources are common issues, as are large class 
sizes, 70 on average in Mozambique, the Congo and Chad, 80 in urban parts of Ethiopia and Pakistan (Global Campaign for Education - GCE, 2006, p. 13). Workloads can also be high. In Ghana, teachers are expected to teach over 40 hours per week (Bennell \& Akyeampong, 2007, p. 42).

Another issue is a lack of pre-service training. According to a UNESCO report cited by GCE (2006, p. 26), only a small minority of developing countries can claim that most of their primary teachers have received training. In some countries (e.g. Namibia, Sierra Leone, Uganda), the better trained teachers are in urban areas, with teachers in rural areas much less prepared (Bennell \& Akyeampong, 2007, p. 18). A worrying trend in parts of the world is that there has been a tendency to abandon pre-service training courses in countries that have run these (e.g. Belize, Cambodia, Senegal) and provide instead shortened versions for 'para-teachers'; these para-teachers are also paid less and employed on more casual terms, without any form of career structure (GCE, 2006, p. 16).

A further problem is that in-service training is also very limited in some countries, particularly in rural areas; "a posting to a rural school can be a oneway ticket [that severely affects teachers'] ability to undertake further studies" and thus gain the support they need for personal growth (Bennell \& Akyeampong, 2007, p. 19). When teachers feel that without in-service training they lack the skills to teach a recently-introduced curriculum, as has happened for example in Malawi, it can affect their motivation (VSO, 2002, p. 33).

Professional support within schools is also frequently disappointing. In many countries, such as Ghana, headteachers lack formal training and may owe their positions not to competence but length of service (Bennell \& Akyeampong, 2007, p. 44). Management styles are frequently autocratic. In contexts such as Papua New Guinea and Zambia, teachers have complained of not being listened to, of being criticized in front of pupils and colleagues; females have complained of suffering discrimination and sexual harassment (VSO, 2002, p. 21). In India and Pakistan, where the norm is for rural primary schools to be staffed by just one or two teachers teaching all levels, teachers tend to experience not professional support at school but isolation (Bennell \& Akyeampong, 2007, p. 43).

Professional support from outside the school, from inspectors, is also sporadic, particularly in rural areas. As a result, teachers can lack guidance, e.g. in Pakistan (GCE, 2006, p. 48) or may fail to receive the appraisals that could lead to further professional development, e.g. in Papua New Guinea (VSO, 2002, p. 33). Furthermore, when inspectors do visit, their focus can be more on administrative details than teacher development, as examples from Nigeria demonstrate (Bennell \& Akyeampong, 2007, p. 44). 
In many developing countries, there is also a perceived lack of support from regional authorities, e.g. in Zambia, pay is sometimes late and resources promised to schools are not always provided (VSO, 2002, p. 27). Brazilian teachers complain of neglect and scarce resources (de Lima, 2012), while those in India feel abandoned on the bottom rung of the administrative ladder (Bennell \& Akyeampong, 2007, p. 39).

These various factors have contributed to what has been described as a teacher motivation crisis in the developing world (Bennell \& Akyeampong, 2007, p. vi). Consequences include poor performance, absenteeism and efforts to leave teaching, which is particularly disturbing given that tens of millions of children in developing countries lack even primary education (GCE, 2006, p. 1). To better understand this teacher motivation crisis and how it can be addressed, a theoretical perspective is required. This is the focus of the next section.

\section{Theorizing challenges to teacher motivation in developing countries}

The issue of motivation to teach in a professional and dedicated way consistent with educational goals that involve fostering learning has received relatively little attention in both educational psychology (Dörnyei, 2001) and studies of comparative education (Bennell \& Akyeampong, 2007, p. 3). In the field of educational psychology, the focus in western contexts has tended to be not on teacher motivation in general but on specific dimensions of this construct, e.g. teachers' self-efficacy beliefs (Tschannen-Moran, Woolfolk-Hoy \& Hoy, 1998). Alternatively, researchers have focused on threats to teacher motivation, such as stress and burnout (Vandenberghe \& Huberman, 1999).

In the comparative education literature, the treatment of teacher motivation has been somewhat disappointing. In fact, in the donor agency reports cited above that do treat teacher motivation as a central construct, theoretical perspectives are limited. In fact, despite offering thick, rich description of the motivational challenges teachers face, some of these reports, e.g. VSO (2002) and GCE (2006), do not address theoretical issues at all. In other reports, e.g. for DFID and Save the Children, very dated theoretical models of motivation are used. Thus, Bennell \& Akyeampong (2007) and Guajardo (2011) draw on Maslow's (1943) Hierarchy of Needs and Herzberg's (1966) MotivationHygiene Theory; these models have some explanatory power, which accounts for their enduring appeal, but have also been criticized, e.g. by Heylighen (1992), for offering an incomplete picture. Maslow's (1943) theory, for example, suggests that lower order needs (e.g. for safety) must be met before higher order needs (e.g. for self-esteem) are contemplated. However, it can be argued that in desperate circumstances, even when facing "continuous threat[s] to safety and to life, people still retain some form of dignity and altruism" (Heylighen, 1992, p. 46), and Maslow's (1943) theory does not really account for this. 
Contemporary motivation theories have tended to focus on the importance of goal-achievement, the goal being "seen as the 'engine' to fire the action and provide the direction in which to act" (Dörnyei, 2001, p. 25). Ryan and Deci (2000, p. 69) agree: "Motivation concerns energy, direction, persistence and equifinality - all aspects of activation and intention". The broad motivational framework they developed, Self-Determination Theory (SDT), has attracted numerous academic researchers in recent years (e.g. Lamb [2009], Noels [2009]), and is described below.

Central to SDT (Ryan and Deci, 2000) is the understanding that key to motivated behaviour is an intrinsic component. Humans have "an inherent tendency to seek out novelty and challenges, to extend and exercise" their capacities, to learn and explore (p. 70). If teachers engage enthusiastically in tasks they enjoy, we can describe their motivation as intrinsic.

For intrinsic motivation to flourish, though, certain conditions are required, and a sub-theory within SDT, Cognitive Evaluation Theory (CET) (Ryan and Deci, 2000), focuses on these. One important condition for intrinsic motivation is a feeling of competence. This suggests that if, for example, teachers gain feedback on their work that helps them grow and rise to fresh challenges, their intrinsic motivation will increase. A second condition is a sense of autonomy. So, if teachers feel able, for example, to adjust the curriculum they are using to meet the needs of their learners, they will feel more intrinsically motivated. A third condition is a sense of relatedness. So, feeling psychologically close to people associated with the school environment (colleagues, learners and their families) will also increase intrinsic motivation.

Inevitably, though, much of what people do is not intrinsically motivated and Ryan and Deci (2000) have developed a sub-theory within SDT, Organismic Integration Theory (OIT), to account for other types of motivation, chiefly the extrinsic. Extrinsic motivation is goal-directed, but the goal is not inherent satisfaction but a separable, instrumental outcome, e.g. engaging in a task to please someone else or to support a chosen career. There are different degrees of extrinsic motivation, from external regulation at one extreme (fulfilling a task simply to achieve rewards or avoid punishments) to integrated regulation at the other; the latter is close to intrinsic motivation, as identified regulations have been fully assimilated so that they fit other values and needs harmoniously. When this occurs, and organizational goals have been fully internalized, the level of stimulation and satisfaction is such that the motivation is 'effectively' intrinsic (Van Lier, 1996).

Ryan and Deci (2000) have presented a continuum indicating how motivation can be mapped. At one extreme is intrinsic motivation. At the other is amotivation, which describes what happens when people do not act at all or simply go through the motions, acting without intent, without motivation. In between are four types of extrinsic motivation, including the two (external 
regulation and integrated regulation) mentioned above. Motivation might vary considerably in relation to different tasks, but it is thought that the closer teachers' motivation is to the intrinsic on the SDT continuum the better, as their behaviour will be informed by a greater sense of psychological wellbeing. Relating these concepts to teacher identity, Dörnyei (2009) suggests that those teachers whose motivation is closer to the intrinsic are closer to their ideal (rather than ought) selves. The ideal self "refers to the representation of the attributes that one would ideally like to possess [as opposed to those] one believes one ought to possess... based on someone else's sense of duties, obligations or moral responsibilities" (p. 13). So teachers closer to their ideal selves will have internalized the desired pedagogical behaviour; there will be greater harmony.

An implication of SDT is that if teachers work in supportive environments that encourage the development of a sense of competence, the exercise of autonomy and feelings of relatedness, then they will be able to focus more on the joys of teaching. Their motivation will become more intrinsic (Ryan and Deci, 2000), their behaviour a fulfilment of their ideal selves (Dörnyei, 2009). Unfortunately, though, in many worldwide contexts, teachers can be overwhelmed by negative influences, such as stress, rigid curricula, content repetitiveness, standardized testing, imposed teaching methods, lack of training, an unfavourable school climate, lack of support in the community, low pay and an inadequate career structure (Dörnyei, 2001). Such influences make it harder for teachers to fulfil their various psychological needs for competence, autonomy and relatedness and their intrinsic motivation suffers.

In the developing world, the challenges are all too evident. A Ugandan teacher, quoted by Altinyelken (2010, p. 167), reports, for example:

When you are tortured here and there, how can you come and teach enthusiastically and lovingly... When my mind is busy and preoccupied with basic necessities of my own life, how can you expect me to perform well in the classroom?

'Tortured' trying to meet economic needs unfulfilled because of poverty, this teacher has psychological needs, too, for relatedness and competence, as her choice of words, 'teach enthusiastically and lovingly', suggests. However, her preoccupation with 'basic necessities' prevents her from giving her undivided attention to teaching. She thus lacks autonomy, the third key psychological need in SDT (Ryan and Deci, 2000), which also prevents her from fulfilling the other two.

Using SDT (Ryan and Deci, 2000) allows us to analyse how the challenges to teacher motivation in the developing world exert negative influences on different psychological needs that are key to intrinsic motivation. Low salaries reduce teachers' sense of autonomy; so do rigid curricula, standardized testing and teaching methods imposed by a higher authority. A lack of pre- 
service and in-service training can prevent teachers from gaining knowledge and skills that would help them develop both a general sense of competence in their work as well as task-specific self-efficacy beliefs (Wyatt, 2012a). Unsupportive management, unresponsive students and either uncooperative peers or isolation (in the case of teachers working on their own in rural schools) all reduce teachers' sense of relatedness.

A likely consequence of suffering from these negative influences is extrinsically motivated behaviour. There might be less concern with the joys of teaching than with separable outcomes, such as appraisals of their work conducted by remote authority figures or with a conscious need to follow externally imposed rules (Dörnyei, 2009). Teachers might have problems if they do not achieve these outcomes, but if they do, they can at least gain satisfaction from avoiding censure or feelings of guilt. Though this might inculcate no further love of teaching, these extrinsically motivated teachers might nevertheless be motivated to carry on.

There is a more disturbing scenario, though, which concerns teachers who lack motivation, either with regard to specific tasks or across multiple aspects of their work, as an outcome will be non-engagement. Indications of the extent of the problem with amotivation can be gained from studies that have looked at teacher absences in the developing world. These absences are significant. Kremer et al. (2005), for example, reported $25 \%$ of teachers were absent and $50 \%$ not teaching during unannounced visits to a nationally representative sample of Indian primary schools. They also reported high absences in Uganda (27\%) and Indonesia (19\%), while another study (Alcázar et al., 2006) has reported on the situation in Peru. While only $11 \%$ of Peruvian teachers overall were absent, this rose to $16 \%$ and $21 \%$ respectively when the focus was narrowed to poor and remote districts. Some of these absences might, of course, have been legitimate, but researchers have identified a relationship between teacher absence and a challenging work context (Alcázar et al. [2006], Kremer et al. [2005]).

Clearly, then, there are problems with negative contextual influences shaping amotivation and the darker side of extrinsic motivation that need to be addressed. SDT (Ryan and Deci, 2000) suggests it is vital for the well-being of teachers in developing countries, as well as for their students, that support that meets psychological needs key to intrinsic motivation (relatedness, autonomy and competence) is provided. However, for this support to be effective, it may require the coordinated efforts of school and government administration, curriculum and supervision departments and teacher training in ways sensitive to unique socio-cultural contexts.

The next section of this paper focuses on how issues of teacher motivation have been addressed in Oman, a country whose education system, particularly with regard to English language teaching (which is why this is 
examined here), has recently been subject to much research. This emerging literature is first used to explore the extent to which environmental factors that can negatively impact teacher motivation appear to have been addressed. Secondly, evidence of intrinsic motivation is sought in qualitative case study research centred on Omani English teachers.

\section{The Omani context: To what extent have environmental factors that can negatively impact teacher motivation been addressed in recent decades?}

\section{Background}

Oman's current situation needs to be placed in a historical context, as just over 40 years ago the education sector was almost non-existent. A brief historical overview will provide insights into how educational development has progressed rapidly in recent decades, resulting in improved participation and higher literacy rates, the recruitment and continuing education of Omani teachers, and the provision of modern facilities, technology and child-centred curricula.

In 1970, when His Majesty Sultan Qaboos came to power, there were just three schools, all primary, in the whole country, educating approximately 900 students (all male) and employing fewer than 30 teachers; literacy rates were low. Improving education was prioritized and rapid growth followed. By 1980, there were nearly 400 schools educating over 100,000 students (approximately one third of these students were girls). By 1995, nearly half a million children (including as many girls as boys) attended approximately 1,000 schools (Rassekh, 2004; Atkins \& Griffiths, 2009). There have been increases in the number of schools since, though these have been more gradual, to cater to the still growing population.

Furthermore, participation rates amongst young people are now as high as in many Western countries. For example, in 2008, it was estimated that over $80 \%$ of both girls and boys between the ages of 16 and 18 were still in full-time education (Klassen et al., 2011). There are now nearly 40,000 Ministry of Education-employed teachers (Al-Kharusi \& Atweh, 2008).

There have been several phases in the development of the education sector. In the 1970s, the initial concern was to expand access rapidly. Schooling took place in tents or under the shadow of trees (Al-Kharusi \& Atweh, 2008). Resources were limited and local teachers had little formal training (Wilkinson \& Al-Hajry, 2007). Expatriate teachers from North Africa and South Asia (Atkins \& Griffiths, 2009), as well as British curriculum authors and inspectors (Al-Issa, 2005), were employed.

Teacher training colleges were established from 1984 to prepare the first generation of Diploma-holding Omani teachers (Atkins \& Griffiths, 2009); the Education faculty of Sultan Qaboos University also started preparing teachers 
from 1986. In the 1980s, a 'General Education' system was introduced (Rassekh, 2004), with schools custom-built in simple, cost-effective ways. Long, narrow classrooms to hold up to 45 students were equipped with blackboards; chairs and desks were organized in rows; curriculum materials were produced for the local context, their examples rooted in Omani rural life.

The next main phase was initiated in 1995 following a 'Vision 2020' conference on Oman's economic future. For the time ahead, when the country's limited oil reserves would be exhausted, Omanis needed to be equipped to succeed in a globalizing world without depending on expatriates (Rassekh, 2004).

'Basic Education' was introduced (to be phased in gradually) and an ambitious school-building programme was initiated; the new schools had computer rooms and learning resource centres; the classrooms, much broader in design to facilitate groupwork, were equipped with whiteboards and electronic equipment; class size at 25-35 was smaller; the teaching of science was emphasized and English was introduced from Grade 1, rather than from Grade 4, as previously (Ministry of Education - MOE, 2001). There are various political and economic reasons why English, an increasingly important lingua franca in Oman (Fussell, 2011), is the first foreign language taught at school. English is intimately linked with the concept of progress in public discourse in the Arabian Gulf (Karmani, 2005). A declared aim of the new school system was that children's personal and social development would be supported through the provision of a learner-centred cross-curricular experience providing knowledge, skills, attitudes and values for life (MOE, 2001). The new English curriculum, 'English for Me', included Total Physical Response activities, action songs and rhymes, games and craft activities to encourage children to play with the language and learn by doing (English Language Curriculum Department, 2001).

Empowering Omani teachers to contribute to curriculum renewal was an important government objective in the late 1990s (Atkins \& Griffiths, 2009). Short in-service courses focused on methodological issues were provided as well as management courses for senior teachers who had mentoring roles in the new Basic Education schools. Diploma-holding graduates from the teacher training colleges were offered the opportunity to study for Bachelor degrees and over 900 English teachers took the University of Leeds BA Educational Studies (TESOL) through part-time study over three years (in six successive cohorts) while teaching four days per week. They were supported in regional centres by mentoring tutors, who taught, observed and gave feedback (Atkins, Lamb \& Wedell, 2009). The course, assessed through exams and practical assignments, met criteria for constructivism (Dangel \& Guyton, 2004), as it could be tailored, to some extent, to teachers' context-specific needs (Wyatt, 2009; 2010a). Many graduates now occupy senior posts within 
the Ministry of Education, with responsibilities including those for curriculum and supervision (Wedell \& Atkins, 2009).

Government-sponsored change has thus partially transformed the learning/ teaching environment in Oman in recent decades. Nevertheless, challenges remain in English language teaching. In a government-sponsored drive in the last decade to employ more Omanis in the teaching profession, beginning teachers were recruited from private universities, some with lower entry requirements than Sultan Qaboos University, and their language competence has been questioned (Al-Balooshi, 2009). The curriculum has also come under criticism (Al-Issa, 2009) and there are concerns about school leavers' levels of communicative competence in English as they approach the job market (AlMahrooqi, 2012). This job market is difficult to access (Swailes et al., 2012), which can lead to frustration that can spread through the education system. Any discussion of educational change in Oman, and specifically of how environmental factors that can negatively impact teacher motivation have been addressed, needs to be framed by the understanding that government policies in education will need to keep evolving to meet fresh challenges.

\section{Environmental factors}

Focusing on the current situation in Oman, the various environmental factors that can reduce teachers' sense of competence, autonomy and relatedness, and intrinsic motivation (Ryan and Deci, 2000) will now be considered in more detail. The specific focus will be on Omani English teachers, though some of the points below also relate to teachers of other subjects.

\section{Salaries and job security}

Firstly, Omani teachers now have secure, well-paid jobs, a change which has reduced threats to their autonomy. Salaries compare favourably with those of other government employees who have been educated to a similar level (Klassen et al, 2011); compared to police officers or nurses, they are much better off. However, many teachers also have large extended families to care for; supporting these in a culture that places a high value on family is expected. In a recent survey of 150 teachers in one region of the country, AlHabsi (2009, p. 235) found that nearly half agreed with the statement: 'My salary is less than I deserve'. A majority, though, also agreed their profession was secure and safe. There is a lack of reported evidence of Omani teachers needing to supplement their salaries with second jobs, though some may do so.

\section{Location}

While new teachers are often initially required to work in distant regions, staying in hostel accommodation during the week, after several years most gain transfers. Al-Habsi (2009) suggests that being able to work in schools close to home makes teaching a more attractive profession. It should strengthen a sense of relatedness. 


\section{Working conditions}

The school building programme has transformed the learning environment, as schools with computer rooms have replaced tents. Air-conditioning is provided even in remote desert locations, where the school's generator is sometimes the only local electricity source. A more comfortable environment should facilitate a more autonomous focus on teaching and learning. However, air-conditioning is not always well-maintained (Wyatt, 2011a). Positive, intrinsically-motivating features of Basic Education schools include colourful posters decorating spacious, uncrowded classrooms well-resourced with teaching materials; tables are organized for interactive groupwork (Wyatt, 2010a). However, a lack of storage space can be problematic for English and science teachers (Wyatt, 2010b); having to carry their equipment to class might reduce feelings of autonomy. Furthermore, the school building programme is ongoing. There are still older General Education schools being modernized and they can be less motivating places to work in.

\section{Workloads}

Many teachers teach twenty-five 40-minute periods per week or more (Al-Issa, 2009) and, in Al-Habsi's (2009) study, teachers' biggest complaints were about their intensive teaching workloads and the inadequate time made available at school for them to carry out related administrative work. Heavy workloads reduce a sense of autonomy and make it harder to achieve feelings of competence. The problem may be widespread. In a survey of 84 teachers in another region, Al-Balushi (2009) found that the biggest challenges reported were having an excess of five periods per day and covering lessons for absent colleagues. Other issues that concerned teachers were the amount of work involved in administering continuous assessment and the length of the teaching day, which has increased from 4-5 to 6-7 hours in recent years.

\section{The curriculum}

Oman has invested considerably in new, avowedly learner-centred curriculum materials (English Language Curriculum Department, 2001), very different from the "heavily content-laden, teacher-centred" ones (Atkins \& Griffiths, 2009, p.2) that preceded 'English for Me'. 'Our World through English', for example, which was phased out in the last decade, did not contain meaning-focused pairwork or groupwork. Nevertheless, while the new curriculum materials are considered an improvement in some ways (Wyatt, 2011b), they are also centrally produced, which can restrict the autonomy of teachers (El-Okda, 2005). Furthermore, detailed lesson plans are provided, which can present a challenge to novices (Martin, 2011), threatening their sense of competence. While there is scope for teacher and learner creativity, with assessment, for example, now partially continuous (e.g. through projects and portfolios), the agenda is also set by national tests (AlIssa, 2007), which again can negatively impact the autonomy of teachers. 
Professional development through degree courses

One major way in which feelings of competence have been boosted is that, since 1998, Oman has invested considerably in teacher development. Major beneficiaries are the thousands of Diploma-holding graduates of teacher training colleges of all subjects who upgraded to Bachelor degrees. Lamb (2009) administered an SDT questionnaire to 102 members of a cohort of the BA TESOL programme before they started (in December 2005) and as they approached the end of the course (in July 2008), and also conducted follow-up qualitative interviews with nine participants. Summarizing results, Lamb reported "confidence and enjoyment increased significantly [while] motivation remained mainly autonomous" (p. 45), positive findings that may have been a consequence of the teachers' appreciation of the course deepening over time. At the outset (in December 2005), many expected that the main benefit would be English language development. In contrast, two and a half years later, as many as $74 \%$ "claimed that the course had helped them improve their teaching" (p. 42). Lamb concluded that "if teaching was an important part of their identity", this fresh insight would have endorsed their efforts and boosted their intrinsic motivation (p. 45).

Similarly, after conducting an independent evaluation of the BA project for the Ministry of Education that drew upon data from questionnaires, observations and interviews, Freeman (2007) identified benefits gained by teachers who participated, such as greater flexibility and adaptability, e.g. with tasks and course materials. He concluded: "The professional confidence and sense of positive professional autonomy observed... are impressive accomplishments" (p. 42).

\section{Professional development through short courses}

Also catering to teachers' sense of competence, short regionally-organized inservice courses cater to groups with different specific needs, e.g. adjusting to teach a new level or curriculum (Etherton \& Al-Jardani, 2009). Many attend (Al-Belushi, 2009), but the limited number of places available can be a source of frustration. In Al-Habsi's (2009) study, for example, centred on a crosssection of teachers with different levels of training and experience in five schools, a majority felt their professional development was neglected at a regional level. So these teachers felt they were gaining insufficient support, which suggests more could be done to help them develop a sense of competence.

\section{Professional relationships at school}

With regard to relatedness, one of the more encouraging findings from AlHabsi's (2009) study was that two-thirds of the teachers surveyed felt positively about the recognition they received from their headteachers. However, a mixed methods survey of 32 beginning teachers in another region suggests that, yet to negotiate their way from the periphery into the centre of the school's community of practice (Lave \& Wenger, 1991), these novices 
found headteachers remote and inaccessible (Al-Balooshi, 2009). In contrast, the beginning teachers in the same study reported much more positive relationships with senior teachers; these were "characterized by friendly discussions and transparency" (p. 94). So the picture is mixed. Regarding the development of a sense of competence, positive contributions include professional development opportunities organized on-site by senior teachers. Including post-lesson discussions and peer observations, these appear to be highly valued (Al-Belushi, 2009; Al-Rasbiah, 2009). There is growing evidence of senior teachers developing reflective skills in conducting discussions in faciliative ways (e.g. Al-Sinani, 2009).

\section{Professional relationships in the community}

Outside school, it seems from Al-Habsi's (2009) study that relationships between teachers and parents could improve. Only a third of the teachers surveyed reported feeling valued by parents. There are numerous initiatives (e.g. Al-Biloshi, 2009) to involve parents at school. These might be required to build a sense of relatedness.

\section{Professional relationships with supervisors}

Approaches to teacher inspection (now supervision) appear to be changing, away from a more traditional directive role, as highlighted in Wyatt (2010a, 2011a), and towards a more facilitative one, supportive of the development of reflective practice (Al-Zadjali, 2009). Such an approach is more likely to build a sense of competence. However, a survey of $10 \%$ of the teachers in one region conducted by A'Shizawi (2009) suggests some supervisors could further develop interpersonal skills to allow "trust, respect and a sense of shared understanding [to] inform the mutual dialogue" (p. 10).

\section{Career advancement}

Of the teachers in Al-Habsi's (2009) study, nearly half felt they had sufficient opportunities for promotion, while nearly two-thirds expected a good career in education (which may also reflect their sense of job security). This suggests these teachers may have felt closer to the establishment and to institutional goals, and were thus perhaps closer to the intrinsic end of the SDT continuum (Ryan and Deci, 2000). There are increased opportunities for promotion under the Basic Education system; the policy is for all schools with at least four teachers of any particular subject to have a senior teacher.

\section{Summary}

The findings above reveal a mixed picture, with some environmental factors clearly more supportive of intrinsically-motivated teaching than others. Better school buildings and facilities, and improved salaries allow teachers to focus more fully on their work, encouraging a sense of autonomy. Reduced class sizes under Basic Education, the creation of senior teacher posts to fulfil mentoring roles, promotion opportunities and the chance to teach close to home all support feelings of relatedness. Professional development 
opportunities organized within the school by senior teachers, short courses managed locally by regional trainers, and inspection/supervision focused on the development of reflective practice all support a growing sense of competence. Extensive university teacher education that includes mentoring (such as the BA programme) clearly does this too and helps teachers become more autonomous, a goal too of other forms of professional development.

However, clearly there are still threats to the intrinsic component of teachers' motivation. Heavy workloads, a centralized curriculum and standardized tests all reduce autonomy. Poor relationships with school administrators or with parents in the local community can reduce a sense of relatedness. Uneven or limited access to the professional development opportunities available can thwart aspirations to grow in competence. As to how individual teachers are affected, much depends on the micro-context, individual characteristics and the particularities of experience.

\section{What case study evidence is there of intrinsic motivation amongst Omani English teachers?}

To address this question, published qualitative case studies of Omani English teachers have been reviewed for evidence of the autonomy, relatedness and sense of competence that are key to intrinsically-motivated behaviour (Ryan \& Deci, 2000). However, there are few studies of Omani English teachers available and most of these relate to one multi-case study of five teachers on the University of Leeds BA TESOL (Wyatt, 2008). Conducted by a regional tutor on this project, this focused on the teachers' developing practical knowledge and self-efficacy beliefs, following growth longitudinally over three years.

Various qualitative research methods were used in this study (Wyatt, 2008). Observations in which the observer had a non-participant role (Cohen, Manion and Morrison, 2007) provided insights into the teachers' classroom practices; each teacher was observed once a semester, with each observation lasting 35-40 minutes. The observer kept a narrative record. Observations were always followed by semi-structured interviews (Kvale and Brinkmann, 2008), which drew upon the use of observation notes to stimulate recall, encouraging teachers both to reflect on their actions in a specific classroom context and to relate these reflections to underlying cognitions and environmental factors. Interviews were 40-50 minutes in length. A third method used was the analysis of reflective assignments teachers completed for the BA TESOL; these (of 3-6,000 words in length) often reported on action research. 25 assignments were analysed as well as 27 observations and 38 interviews. From the perspective of the researcher (Wyatt, 2008), this combination of methods was useful, as it was possible to compare observed and described practice, oral and written reflections, and to examine changes over time, thus allowing various forms of triangulation (Stake, 1995). In 
analysing and writing up data, the researcher tried to be reflexive in various ways, e.g. by triangulating personal judgements of innovations described in the teachers' reflecting writing with assignment feedback produced by University of Leeds markers, by incorporating 'member checking' (Stake, 1995), and by showing work to a critical friend (Wyatt, 2008).

The five teachers studied were all volunteers who gave informed consent, guaranteeing anonymity, confidentiality and the right to withdraw at any time, in accordance with ethical guidelines. They included both males and females from a range of different types of school, primary and secondary, in urban and rural locations, so in the selection of cases there was balance and variety (Wyatt, 2008). However, over three-quarters of Omani English teachers currently practising are (mostly younger) graduates of other universities, so these five are hardly representative of Omani English teachers as a whole. Moreover, they were from the same region, studying with the same cohort, with the same tutor. Furthermore, besides being on an intrinsically-motivating course (Lamb, 2009), they had all also chosen to do action research dissertations, a choice which, in itself, implies a degree of intrinsic motivation. The study did include 'deviant case analysis' (Silverman, 2000); i.e. one teacher developed in an unexpected way. However, the theoretical sampling employed made it more likely that intrinsicallymotivated teachers would be selected. Accordingly, the research question chosen for this paper has been framed with this inherent bias in mind. It should, therefore, be emphasised that findings need to be treated cautiously. As Stake (1995, p. 8) reminds us, though: "the real business of case study is particularization".

The other study examined here, conducted by a regional supervisor of English (Al-Balooshi, 2009), is of a beginning teacher, recruited from a private university during a government-sponsored drive to recruit more Omani teachers. As a newcomer, it is thought she would have been trying to negotiate her way towards the centre of the school's community of practice (Lave \& Wenger, 1991). She completed a questionnaire (as did 31 other beginning teachers), which asked about relationships within the school (with headteacher, senior English teacher, other English teachers and teachers of other subjects) and access provided by these groups. On a five-point Likert scale, level of agreement was elicited to statements such as: 'The headmistress talks to me every now and then regarding my concerns about work', 'Generally speaking, I have a good rapport with my English language colleagues', 'I found it easy to share my concerns with the senior teacher at the beginning of this [academic] year' (Al-Balooshi, 2009, p. 93-95).

Guaranteed anonymity and confidentiality, the teacher was one of those who volunteered to take part in the next stage of the research. She was interviewed, as were her school's senior teacher and headteacher, with each interview lasting about 45 minutes and including open-ended questions to encourage richness of expression and spontaneity (p. 92). One of the researcher's 
concerns was whether she, like other graduates from the same university, might be suffering from negative stereotyping on the basis of her academic qualifications (p. 99).

It should be emphasized that these studies were not specifically focused on SDT (Ryan and Deci, 2000). Limitations in this form of data repurposing must be acknowledged. However, these case studies do nevertheless provide sufficiently 'thick description' (Geertz, 1973) for insights to be gained into the degree to which the teachers were intrinsically-motivated. This allows illustrative snapshots to be presented (Table 1).

As Table 1 (overleaf) illustrates, a range of micro-contextual environmental factors can impact teachers' motivation, affecting where this lies on Ryan and Deci's (2000) SDT continuum. A key issue is the extent to which these factors inhibit or facilitate the fulfilment of psychological needs for relatedness, competence and autonomy. Several of these teachers (Sarah, Mariyam and Waleed) seem to have been 'effectively' intrinsically-motivated (Van Lier, 1996) and Table 1 suggests why this was the case. Firstly, although Sarah expressed herself more cautiously with regards to handling some of the challenging contextual factors (Wyatt, 2009), she also had positive self-esteem, and confidence she could rise to challenges (Wyatt, 2011b). Mariyam and Waleed both expressed themselves efficaciously. Secondly, all three experienced a strong sense of relatedness with learners and immediate colleagues and, thirdly, all had sufficient autonomy to enact changes in their practice. This fulfilment of psychological needs appeared to contribute to positive outcomes, which may, in turn, have supported further growth. Interestingly, negative environmental factors that Sarah and Waleed were conscious of did not appear to lead them to less intrinsically-motivated behaviour. In relation to the tasks they focused on, they were able to teach in the way they wanted to, in tune with their ideal selves (Dörnyei, 2009). Observational data (Wyatt, 2009; 2010a; 2011a) suggest these teachers rose above challenges.

A consideration of the other cases, though, suggests a rather different picture. Rashid appears to have been an intrinsically-motivated teacher thwarted by lack of autonomy and frustrated by an inability to persuade, impacting his sense of relatedness (Wyatt, 2010b). The consequence was amotivated behaviour in relation to using groupwork; he gave up. Zahra's behaviour was also amotivated (Al-Balooshi, 2009). Her sense of competence was challenged (she felt the headteacher doubted her ability to teach), she lacked autonomy (instructed on what to do) and her sense of relatedness was poor (relationships worsened). It is perhaps not surprising she wished to transfer to another school. In contrast, Omar's behaviour was extrinsically-motivated in some ways (Wyatt \& Borg, 2011; Wyatt, 2012b). Though not a novice like Zahra, he was in a new school where he had yet to build positive 


\begin{tabular}{|c|c|c|c|c|c|c|c|c|}
\hline Teachers & $\begin{array}{l}\text { Years } \\
\text { exp. }\end{array}$ & Study & Focus & $\begin{array}{l}\text { Challenging } \\
\text { environmental factors }\end{array}$ & Sense of relatedness & Sense of competence & Sense of autonomy & $\begin{array}{l}\text { Behavioural } \\
\text { outcomes }\end{array}$ \\
\hline Sarah & $\begin{array}{l}12 \\
\text { years }\end{array}$ & $\begin{array}{l}\text { Wyatt } \\
(2009 ; \\
2010 c ;), \\
\text { Wyatt \& } \\
\text { Borg }(2011)\end{array}$ & $\begin{array}{l}\text { Learning to use } \\
\text { communicative } \\
\text { language teaching } \\
\text { (CLT) methodology } \\
\text { with teenagers }\end{array}$ & $\begin{array}{l}\text { Large class sizes, } \\
\text { resistance of colleagues } \\
\text { to having classrooms } \\
\text { organized for } \\
\text { groupwork, broken } \\
\text { photocopier }\end{array}$ & $\begin{array}{l}\text { Committed to helping } \\
\text { learners develop } \\
\text { speaking skills; had good } \\
\text { relationships with } \\
\text { colleagues and access to } \\
\text { the headteacher }\end{array}$ & $\begin{array}{l}\text { Had positive self- } \\
\text { esteem; expressed } \\
\text { some doubts but } \\
\text { benefited from } \\
\text { positive efficacy- } \\
\text { building experiences }\end{array}$ & $\begin{array}{l}\text { Felt able to } \\
\text { innovate to create } \\
\text { and use } \\
\text { communicative } \\
\text { tasks despite } \\
\text { constraints }\end{array}$ & $\begin{array}{l}\text { Effectively } \\
\text { intrinsically- } \\
\text { motivated; teaching } \\
\text { became more } \\
\text { learner-centred and } \\
\text { communicative }\end{array}$ \\
\hline Zahra & $\begin{array}{l}1 \\
\text { year }\end{array}$ & $\begin{array}{l}\text { Al-Balooshi } \\
(2009)\end{array}$ & $\begin{array}{l}\text { Coping with the } \\
\text { first year's teaching }\end{array}$ & $\begin{array}{l}\text { On the periphery of the } \\
\text { school's community of } \\
\text { practice, finding it } \\
\text { difficult to negotiate } \\
\text { access to the centre }\end{array}$ & $\begin{array}{l}\text { Felt intimidated by the } \\
\text { headteacher, who felt she } \\
\text { had an 'inferiority } \\
\text { complex'; liked the 'frank } \\
\text { and tough' senior teacher } \\
\text { but did not trust peers }\end{array}$ & $\begin{array}{l}\text { Felt frightened when } \\
\text { the headteacher } \\
\text { observed \& learners } \\
\text { did not participate; } \\
\text { her ability was } \\
\text { questioned }\end{array}$ & $\begin{array}{l}\text { Had her own ideas } \\
\text { regarding } \\
\text { groupwork, but } \\
\text { was 'instructed' in } \\
\text { post-lesson } \\
\text { discussions }\end{array}$ & $\begin{array}{l}\text { Amotivated; } \\
\text { withdrew from } \\
\text { colleagues and } \\
\text { wanted to transfer } \\
\text { to another school }\end{array}$ \\
\hline Mariyam & $\begin{array}{l}8 \\
\text { years }\end{array}$ & $\begin{array}{l}\text { Wyatt } \\
(2010 \mathrm{a}, \\
2010 \mathrm{c}), \\
\text { Wyatt \& } \\
\text { Arnold } \\
(2012)\end{array}$ & $\begin{array}{l}\text { (as senior teacher) } \\
\text { reflecting, helping } \\
\text { teachers develop as } \\
\text { reflective } \\
\text { practitioners }\end{array}$ & $\begin{array}{l}\text { Teachers felt anxious } \\
\text { when asked by } \\
\text { inspectors to reflect on } \\
\text { their lessons in English }\end{array}$ & $\begin{array}{l}\text { Felt close to learners, } \\
\text { enjoyed the support and } \\
\text { trust of headteacher \& } \\
\text { teachers }\end{array}$ & $\begin{array}{l}\text { Felt appreciated; } \\
\text { gained positive } \\
\text { efficacy-building } \\
\text { experiences in } \\
\text { mentoring }\end{array}$ & $\begin{array}{l}\text { Felt able to } \\
\text { innovate creatively } \\
\text { in mentoring } \\
\text { discussions }\end{array}$ & $\begin{array}{l}\text { Effectively } \\
\text { intrinsically- } \\
\text { motivated; } \\
\text { developed very } \\
\text { well as a mentor }\end{array}$ \\
\hline Rashid & $\begin{array}{l}9 \\
\text { years }\end{array}$ & $\begin{array}{l}\text { Wyatt } \\
(2010 b \\
2010 c)\end{array}$ & $\begin{array}{l}\text { Using groupwork } \\
\text { to support low } \\
\text { achievers }\end{array}$ & $\begin{array}{l}\text { Classroom } \\
\text { arrangements for } \\
\text { English teaching were } \\
\text { not ideal; colleagues } \\
\text { saw low achievers as } \\
\text { hopeless }\end{array}$ & $\begin{array}{l}\text { Cared about low } \\
\text { achievers, but found it } \\
\text { hard to convince some } \\
\text { learners to re-group; tried } \\
\text { but could not influence } \\
\text { headteacher's policies }\end{array}$ & $\begin{array}{l}\text { Became efficacious in } \\
\text { helping low achievers } \\
\text { benefit from some } \\
\text { types of classroom } \\
\text { activity / grouping, } \\
\text { but not all }\end{array}$ & $\begin{array}{l}\text { Felt able to } \\
\text { innovate to some } \\
\text { extent, but also felt } \\
\text { constrained by the } \\
\text { school context }\end{array}$ & $\begin{array}{l}\text { Amotivated in } \\
\text { some ways; } \\
\text { dedicated but } \\
\text { unable to put ideas } \\
\text { into practice and } \\
\text { tended to give up }\end{array}$ \\
\hline Waleed & $\begin{array}{l}8 \\
\text { years }\end{array}$ & $\begin{array}{l}\text { Wyatt } \\
\text { (2010c, } \\
2011 a), \\
\text { Wyatt \& } \\
\text { Borg }(2011)\end{array}$ & $\begin{array}{l}\text { Using materials in } \\
\text { a motivating way } \\
\text { and supporting } \\
\text { other teachers to do } \\
\text { this }\end{array}$ & $\begin{array}{l}\text { Large class sizes, } \\
\text { limited resources, } \\
\text { colleagues with limited } \\
\text { awareness of how to } \\
\text { exploit materials }\end{array}$ & $\begin{array}{l}\text { Had positive } \\
\text { relationships with fellow } \\
\text { teachers, learners and } \\
\text { their families; criticized } \\
\text { remote school } \\
\text { administrators and out- } \\
\text { of-date inspector }\end{array}$ & $\begin{array}{l}\text { Became more } \\
\text { efficacious in } \\
\text { adapting materials, } \\
\text { justifying changes } \\
\text { and supporting } \\
\text { colleagues; felt } \\
\text { appreciated }\end{array}$ & $\begin{array}{l}\text { Felt able to } \\
\text { innovate creatively } \\
\text { in adapting } \\
\text { materials and } \\
\text { showing others } \\
\text { how to do this }\end{array}$ & $\begin{array}{l}\text { Effectively } \\
\text { intrinsically- } \\
\text { motivated; } \\
\text { developed very } \\
\text { well as a materials } \\
\text { developer and had } \\
\text { mentoring skills }\end{array}$ \\
\hline Omar & $\begin{array}{l}10 \\
\text { years }\end{array}$ & $\begin{array}{l}\text { Wyatt \& } \\
\text { Borg } \\
(2011) \\
\text { Wyatt } \\
(2012 b)\end{array}$ & $\begin{array}{l}\text { Helping learners } \\
\text { overcome } \\
\text { difficulties in } \\
\text { reading and } \\
\text { speaking }\end{array}$ & $\begin{array}{l}\text { Remote mountainous } \\
\text { area, new to school, } \\
\text { limited environmental } \\
\text { literacy, rigidly- } \\
\text { standardized } \\
\text { assessment }\end{array}$ & $\begin{array}{l}\text { Reported caring about } \\
\text { learners, but did not } \\
\text { appear close to them and } \\
\text { had poor relationships } \\
\text { with parents, a fellow } \\
\text { teacher and the inspector }\end{array}$ & $\begin{array}{l}\text { Declared he felt } \\
\text { confident and } \\
\text { reported wanting to } \\
\text { make a difference }\end{array}$ & $\begin{array}{l}\text { Wary of inspector; } \\
\text { felt constrained to } \\
\text { follow the } \\
\text { coursebook and } \\
\text { adapted it in only } \\
\text { minor ways }\end{array}$ & $\begin{array}{l}\text { Fairly extrinsically- } \\
\text { motivated; taught } \\
\text { to assessment in a } \\
\text { fairly traditional } \\
\text { way, using few } \\
\text { new ideas }\end{array}$ \\
\hline
\end{tabular}


relationships (and so had a poor sense of relatedness). Worried about the inspector's judgement, he also felt he should follow the teacher's book closely, demonstrating a lack of autonomy in this. Unsurprisingly, therefore, although he was much more creative in extra-curricular activities (Wyatt, 2012b), in the classroom he taught in a traditional way to support assessment. His classroom behaviour, therefore, seemed largely governed by the external regulation of extrinsic motivation (Ryan and Deci, 2000), though some organizational goals may have been partially internalized. His ought self (Dörnyei, 2009) seemed to come to the fore.

These case study data demonstrate, therefore, that, as one would expect, Omani teachers can be found all along the SDT continuum (Ryan and Deci, 2000), from the amotivated to extrinsically- and then intrinsically-motivated. There are various implications. Zahra's case illustrates the need to nurture beginning teachers in a warm, supportive school environment. Al-Balooshi (2009) suggests that training in group dynamics might be useful to school managers, who need to engage, listen actively, monitor progress in an empathetic way, encourage interaction and 'scaffold' professional development. Unless beginning teachers feel "welcome and trusted" (p. 103), gaining a positive sense of relatedness, they are unlikely to thrive.

The cases of Rashid and Omar highlight the role of negative environmental factors in undermining the effectiveness of a teacher education programme. Throughout the BA TESOL, efforts were made to liaise with regional and school authorities to secure better working conditions for course participants, e.g. the reduced teaching loads (Atkins \& Al-Hosni, 2009) that can restrict autonomy. However, such initiatives could only achieve so much. If the headteacher chose to adopt school policies that would negatively affect all teachers in the school, as happened at Rashid's, requests to reconsider could be ineffectual (Wyatt, 2010b). Rashid's 'English room' was taken away and he found it much harder to set up groupwork, which contributed to amotivation.

Rashid was intrinsically-motivated at the start of the BA TESOL (Wyatt, 2010b); this programme was intrinsically-motivating for many others (Lamb, 2009). Sarah, Waleed and Mariyam testify to this, emphasizing that it helped them gain competence and autonomy. Sarah, for example, working with the older curriculum being phased out, reported near the beginning of the course that she wanted to "change everything" to incorporate more CLT into her classes (Wyatt, 2009, p. 9); observational data suggest she did then adapt materials to fulfil this goal in the next two years. Waleed reflected towards the end of the course that he had developed problem-solving skills that helped him persist if attempts at innovation were not immediately successful (Wyatt, 2011a, para. 113); observational data again supported this claim. Mariyam also felt she was more autonomous, able to exploit the syllabus more fully to help her learners "love English"; she was "more patient", better able to "notice important things", act on them, ask questions when activities were not 
working; she was "more reflective", her mind "open", with "the awareness to exploit everything around" her (Wyatt, 2010a, p. 256). Again, observational data were consistent with these assertions.

With the help of 'thick description' (Geertz, 1973), these case studies illustrate how the BA TESOL could be an intrinsically-motivating teacher education programme for some of the participants, a finding consistent with Freeman (2007) and Lamb (2009). However, these case studies also depict how, in the cases of Zahra, Rashid and Omar, negative environmental factors discussed above can reduce feelings of relatedness, competence and autonomy, and thwart intrinsic motivation.

\section{Conclusions}

There are various implications from this study that might be of interest to educational reformers. Firstly, though, several observations about the unique socio-cultural context of Oman are in order. For example, the sultanate's success in developing its education system from almost nothing (three primary schools in 1970 and high illiteracy rates) seems due to good governance that incorporated clear vision, systematically-implemented policies and careful resource management (e.g. of limited revenue from oil). These qualities are evident in Oman's progressive five-year plans for the education sector (Rassekh, 2004).

Secondly, Oman has invested in its teachers. This is striking when one considers that teachers are often forgotten about in the process of educational reform (Bennell \& Akyeampong, 2007), with "nearly all national and donor agency strategies [lacking] a clear focus on the very serious problem of low teacher job satisfaction and motivation" (p. 57). Benefits enjoyed by teachers in Oman include the provision of in-service teacher education, such as the BA TESOL. Evidence presented above suggests this course supported the fulfilment of psychological needs for competence, relatedness and autonomy, and thus intrinsically-motivated behaviour (Ryan and Deci, 2000), when personal and environmental factors allowed.

Nevertheless, it is evident that more could be done to motivate Omani English teachers, e.g. by giving them greater freedom to adapt curriculum materials (Al-Issa, 2007), thus allowing them more autonomy. However, it can also be argued that unpopular education policies are sometimes necessary. E.g. lengthening the school day, while not well-received by some teachers (AlBalushi, 2009), increased learning opportunities. Much depends on how educational policies are implemented. In well-managed schools, such as Mariyam's (Wyatt, 2010a), teachers may be happier. In schools characterized by apparently uncaring management, such as Zahra's (Al-Balooshi, 2009), much unnecessary harm can be done to teachers' psychological well-being. 
A further observation is that for investigating teacher motivation in Oman, SDT (Ryan and Deci, 2000) seems an appropriate theoretical framework. Perhaps, it could be used more widely. Reports on teacher motivation in the developing world produced for donor agencies in the last decade (Bennell \& Akyeampong [2007], GCE [2006], Guajardo [2011] and VSO [2002]) could only have been strengthened, if underpinned by such a clear theoretical model.

This brings me to implications. Firstly, there is evidence here, though limited in scope, that constructivist teacher education (Dangel and Guyton, 2004) can support growing competence and autonomy, psychological needs key to intrinsically-motivated behaviour (Ryan and Deci, 2000). This research thus offers mini-confirmation of the larger-scale studies of Freeman (2007) and Lamb (2009) into the BA TESOL. Teacher educators could act by designing programmes according to constructivist principles, by providing professional development courses on a regular basis and by offering access to materials that support self-development.

Secondly, careful attention needs to be paid to the school environment. If teachers are to be empowered through teacher education, then they need opportunities to engage autonomously in managing their students' learning, which requires a degree of freedom and flexibility with tasks and materials (Freeman, 2007). Furthermore, schoolteachers need nurturing, particularly beginners at the edge of the school's community of practice (Lave \& Wenger, 1991), so that over time they become confident and competent insiders with a sense of belonging. Teamwork can increase relatedness, drawing beginners on the periphery into the centre. Their sense of competence, self-efficacy and selfesteem can be developed through appreciation. If they are treated as trusted professionals and given opportunities to succeed, their intrinsic motivation may increase.

Of course, logistical support is required too, and ambition to foster change. There are lessons for administrators in how Oman's rapid development of the education sector has been managed, and needs for relatedness and autonomy supported. If, for example, teachers in rural schools are provided sufficient logistical help, in the form of equipment and resources, they may feel more autonomous. If postings to remote locations are perceived as duties both shared and time-bound, a sense of relatedness might increase.

Clearly, further research into teacher motivation is required, including that in other geographical and educational contexts that are fast developing. To benefit educational reformers, this could utilize a wider range of research methodologies, including a fuller use of ethnographic case studies, so that teachers' voices are heard. 


\section{References}

A'Shizawi, S.M. (2009). English teachers' attitudes towards the post-lesson discussion in Oman. In M. Wyatt \& J. Atkins (Eds.), Research perspectives on education in Oman (pp. 1-14). Muscat: Ministry of Education, Sultanate of Oman.

Al-Balooshi, A.S. (2009). Beginning teachers' perceptions of their first year's teaching experience. In M. Wyatt \& J. Atkins (Eds.), Research perspectives on education in Oman (pp. 89-104). Muscat: Ministry of Education, Sultanate of Oman.

Al-Balushi, A.S. (2009). English teachers' perceptions of workload. In S. Borg (Ed.), Researching English language teaching and teacher development in Oman (pp. 102-111). Muscat: Ministry of Education, Sultanate of Oman.

Al-Belushi, H.A. (2009). English teachers' perceptions of professional development activities. In S. Borg (Ed.), Researching English language teaching and teacher development in Oman (pp. 92-101). Muscat: Ministry of Education, Sultanate of Oman.

Al-Biloshi, S.S. (2009). Parental support in learning to read English. In S. Borg (Ed.), Understanding English language teaching and learning in Oman (pp. 140-147). Muscat: Ministry of Education, Sultanate of Oman.

Al-Habsi, S.K. (2009). Motivating teachers in times of change. In M. Wyatt \& J. Atkins (Eds.), Research perspectives on education in Oman (pp. 227-245). Muscat: Ministry of Education, Sultanate of Oman.

Al-Issa, A.S.M. (2005). The role of English language culture in the Omani language education system: An ideological perspective. Language, Culture and Curriculum 18, (3), 258-270.

Al-Issa, A.S.M. (2007). The implications of implementing a 'flexible' syllabus for ESL policy in the Sultanate of Oman. RELC Journal, 38 (1), 199-215.

Al-Issa, A.S.M. (2009). Reflection through peer collaboration: A study from Omani ELT classrooms. Iranian EFL Journal, 4, 169-216.

Al-Kharusi, B. \& Atweh, B. (2008, November). Civic participation and educational reform in the Sultanate of Oman. Paper presented at the Australian Association for Research in Education, Brisbane.

Al-Mahrooqi, R. (2012). English communication skills: How are they taught at schools and universities in Oman? English Language Teaching, 5 (4), 124130.

Al-Rasbiah, S.A. (2009). Peer observation: Teachers' beliefs and practices. In S. Borg (Ed.), Researching English language teaching and teacher development in Oman (pp. 46-55). Muscat: Ministry of Education, Sultanate of Oman.

Al-Sinani, S.K. (2009). How senior English teachers support teachers in reflecting on their lessons during post-lesson discussions. In M. Wyatt \& J. Atkins (Eds.), Research perspectives on education in Oman (pp. 31-47). Muscat: Ministry of Education, Sultanate of Oman.

Al-Zadjali, F.H. (2009). Fostering professional development in post-lesson discussions: perceptions of teachers and supervisors. In M. Wyatt \& J. Atkins (Eds.), Research perspectives on education in Oman (pp. 15-30). Muscat: Ministry of Education, Sultanate of Oman. 
Alcázar, L., Rogers, F.H., Chaudhury, N., Hammer, J., Kremer, M. \& Muralidharan, K. (2006). Why are teachers absent? Probing service delivery in Peruvian primary schools. International Journal of Educational Research, 45, 117-136.

Altinyelken, H.K. (2010). Pedagogical renewal in Sub-Saharan Africa: the case of Uganda. Comparative Education 46, (2), 151-171.

Atkins, J. \& Al-Hosni, S. (2009). Implementing the BA project: a ministry perspective. In J. Atkins, M. Lamb \& M. Wedell (Eds.), International collaboration for educational change: The BA Project (pp. 115-131). Muscat: Ministry of Education, Sultanate of Oman.

Atkins, J. \& Griffiths, D. (2009). Background to the BA Educational Studies (TESOL) programme and project. In J. Atkins, M. Lamb \& M. Wedell (Eds.), International collaboration for educational change: The BA Project (pp. 1-10). Muscat: Ministry of Education, Sultanate of Oman.

Atkins, J., Lamb, M. \& Wedell, M. (Eds.). (2009). International collaboration for educational change: The BA Project. Muscat: Ministry of Education, Sultanate of Oman.

Bennell, P. \& Akyeampong, K. (2007). Teacher motivation in Sub-Saharan Africa and South Asia. Grays, Essex: DFID.

Buckler, A. (2011). Reconsidering the evidence base, considering the rural: Aiming for a better understanding of the education and training needs of Sub-Saharan African teachers. International Journal of Educational Development, 31, 244-250.

Cohen, L., Manion, L. \& Morrison, K. (2007). Research methods in education (6 $6^{\text {th }}$ ed.). London: RoutledgeFalmer.

Dangel, J.R. \& Guyton, E. (2004). An emerging picture of constructivist teacher education. The constructivist, 15 (1), 1-35.

de Lima, K.S. (2012, May). Moving towards contextualized ESL teaching. Paper presented at the University of Portsmouth conference: Language in the real world: Theory, Pedagogy, Practice, 12 May 2012.

Dörnyei, Z. (2001). Teaching and researching motivation. Harlow, UK: Pearson Education.

Dörnyei, Z. (2009). The L2 motivational self system. In Z. Dörnyei \& E. Ushioda (Eds.), Motivation, language identity and the L2 self (pp. 9-42). Bristol: Multilingual Matters.

El-Okda, M. (2005). A proposed model for EFL teacher involvement in ongoing curriculum development. Asian EFL Journal, 7 (4), 33-49.

English Language Curriculum Department (2001). English for me, Teacher's Book 3A. Ministry of Education, Sultanate of Oman.

Etherton, S. \& Al-Jardani, M. (2009). Recent developments in in-service language teacher education in Oman. In J. Atkins, M. Lamb \& M. Wedell (Eds.), International collaboration for educational change: The BA Project (pp. 191-200). Muscat: Ministry of Education, Sultanate of Oman.

Freeman, D. (2007). Fourth evaluation of the Ministry of Education, Oman University of Leeds BA Educational Studies (TESOL) Project. Muscat: Ministry of Education, Sultanate of Oman. 
Fussell, B. (2011). The local flavour of English in the Gulf. English Today, 108, 26-32.

Geertz, C. (1973). The interpretation of cultures: Selected essays. New York: Basic Books.

Global Campaign for Education (2006). Teachers for all: what governments and donors should do. Brussels: GCE.

Guajardo, J. (2011). Theoretical framework, situation analysis of Save The Children country offices, and recommended strategies. Ryde, UK: Save The Children

Herzberg, F.I. (1966). Work and the nature of man. Cleveland: World Publishing.

Heylighen, F. (1992). A cognitive-systemic reconstruction of Maslow's theory of self-actualization. Behavioral Science 37, 39-57

Karmani, S. (2005). Petro-linguistics: The emerging nexus between oil, English and Islam. Journal of Language, Identity and Education, 4 (2), 87-102.

Klassen, R.M., Al-Dhafri, S., Hannok, W. \& Betts, S.M. (2011). Investigating pre-service teacher education across cultures using the teachers' ten statements test. Teaching and Teacher Education, 27, 579-588.

Kremer, M., Muralidharan, K., Chaudhury, N., Hammer, J. \& Rogers, F.H. (2005). Teacher absence in India: A snapshot. Journal of the European Economic Association, 3 (2-3), 658-667.

Kvale, S. \& Brinkmann, S. (2008). Interviews: Learning the craft of qualitative research interviewing (2nd ed.). Thousand Oaks: Sage.

Lamb, M. (2009). Participant motivation on the BA Educational Studies (TESOL) programme: A self-determination perspective. In J. Atkins, M. Lamb \& M. Wedell (Eds.), International collaboration for educational change: The BA Project (pp. 35-47). Muscat: Ministry of Education, Sultanate of Oman.

Lave, J. \& Wenger, E. (1991). Situated learning: Legitimate peripheral participation. Cambridge: CUP.

Martin, R.A. (2011). Service projects and women's agency in Salalah, Oman: A portrait of pre-service Dhofari English teachers. International Journal of Educational Development. Advance online publication. doi:10.1016/j.ijedudev.2011.05.002

Maslow, A.H. (1943). A theory of human motivation. Psychological Review, 50 (4), 370-396.

Ministry of Education. (2001). Basic Education in the Sultanate of Oman: The theoretical framework. Muscat: Ministry of Education, Sultanate of Oman.

Noels, K.A. (2009). The internalisation of language learning into the self and social identity. In Z. Dörnyei \& E. Ushioda (Eds.), Motivation, language identity and the L2 self (pp. 295-313). Bristol: Multilingual Matters.

Rassekh, S. (2004). Education as a motor for development: Recent education reforms in Oman with particular reference to the status of women and girls. Geneva: UNESCO.

Ryan, R.M. \& Deci, E.L. (2000). Self-determination theory and the facilitation of intrinsic motivation, social development and well-being. American Psychologist, 55 (1), 68-78.

Silverman, D. (2000). Doing qualitative research. London: Sage. 
Stake, R.E. (1995). The art of case study research. Thousand Oaks, California: Sage.

Swailes, S., Al-Said, L.G. \& Al-Fahdi, S. (2012). Localisation policy in Oman: a psychological contrasting interpretation. International Journal of Public Sector Management 25 (5), 357-372.

Tschannen-Moran, M., Woolfolk-Hoy, A. \& Hoy, W.K. (1998). Teacher efficacy: Its meaning and measure. Review of Educational Research, 68, 202-248.

United Nations Development Fund (2010). The real wealth of nations: Pathways to human development. New York: UNDP.

Vandenberghe, R. \& Huberman, A.M. (1999). Understanding and preventing teacher burnout: a sourcebook of international research and practice. Cambridge: CUP.

van Lier, L. (1996). Interaction in the language curriculum. Harlow: Longman.

Voluntary Services Overseas (2002). What makes teachers tick?: A policy research report on teachers' motivation in developing countries. London: VSO.

Wedell, M. \& Atkins, J. (2009). The BA project as an example of large-scale educational change. In J. Atkins, M. Lamb \& M. Wedell (Eds.), International collaboration for educational change: The BA Project (pp. 201211). Muscat: Ministry of Education, Sultanate of Oman.

Wilkinson, R. \& Al-Hajry, A. (2007). The global higher education market: The case of Oman. In M. Martin (Ed.), Cross-border higher education: regulation, quality assurance and impact (pp. 129-180). Paris: UNESCO.

World Bank (2011). How we classify countries. Retrieved 25 June 2011 from the website: http:// data.worldbank.org/about/country-classifications

Wyatt, M. (2008). Growth in practical knowledge and teachers' self-efficacy during an in-service BA (TESOL) Programme. Unpublished PhD dissertation, School of Education, University of Leeds, UK.

Wyatt, M. (2009). Practical knowledge growth in communicative language teaching. TESL-EJ, 13 (2), 1-23.

Wyatt, M. (2010a). One teacher's development as a reflective practitioner. Asian EFL Journal, 12 (2), 235-261.

Wyatt, M. (2010b). An English teacher's developing self-efficacy beliefs in using groupwork. System, 38 (4), 603-613.

Wyatt, M. (2010c). Teachers researching their own practice. ELT Journal, 65 (4), 417-425.

Wyatt, M. (2011a). Becoming a do-it-yourself designer of English language teaching materials. Forum: Qualitative Social Research 12 (1), Art 33, 1-38.

Wyatt, M. (2011b). Overcoming low self-efficacy beliefs in teaching English to young learners. International Journal of Qualitative Studies in Education 26 (2), 238-255. (first published online 18 October 2011).

Wyatt, M. (2012a). Towards a re-conceptualization of teachers' self-efficacy beliefs: tackling enduring problems with the quantitative research and moving on. International Journal of Research and Method in Education DOI:10.1080/1743727X.2012.742050 (advance access, first published online 12 November 2012) 
Wyatt, M. (2012b). Issues in supporting the teaching of reading in English as a second language to Arabic-speaking children. The Reading Matrix 12 (2), 146-162.

Wyatt, M. \& Arnold, E. (2012). Video-stimulated recall for mentoring in Omani schools. International Journal of Mentoring and Coaching in Education 1 (3), 218-234.

Wyatt, M. \& Borg, S. (2011). Development in the practical knowledge of language teachers: A comparative study of three teachers designing and using communicative tasks on an in-service BA TESOL programme in the Middle East. Innovation in Language Learning and Teaching, 5 (3), 233-252.

Please cite as:

Wyatt, M. (2013). Motivating teachers in the developing world: insights from research with English language teachers in Oman. International Review of Education 59 (2), 217-242.

http://link.springer.com/article/10.1007/s11159-013-9358-0 